\title{
低摩擦型すべり支承と積層ゴム・ダンパーを組合せた免震構造の エネルギーの釣合に基づく応答予測法
}

\section{ENERGY BALANCE-BASED SEISMIC RESPONSE PREDICTION METHODS FOR SEISMIC ISOLATED BUILDINGS WITH RUBBER BEARINGS, DAMPERS AND LOW FRICTION ELASTIC SLIDING BEARINGS}

\author{
千 葉陽一*, 薩川恵一**, 北村春 幸***, 小山慶 樹* \\ Youichi CHIBA, Keiichi SATSUKAWA, Haruyuki KITAMURA \\ and Yoshiki KOYAMA
}

\begin{abstract}
Recently, low friction elastic sliding bearings are installed seismic isolated buildings with rubber bearings and dampers. Low friction elastic sliding bearings enable the base isolation system with longer natural period than the buildings with rubber bearings and dampers. A method to predict the response of this type of structures based energy balance theory is introduced in this paper. Natural period should be estimated energy spectrum and maximum deformation in consideration of effect of energy absorption and residual deformation. A design methodology of seismic isolated buildings with low friction elastic sliding bearings, that is based an energy balance, is presented.
\end{abstract}

\author{
Keywords : Seismic Isolated Building, Energy Balance, Seismic Response Prediction Methods, Low Friction \\ Elastic Sliding Bearings \\ 免震構造，エネルギーの釣合，地震応答予測，低摩擦型すべク支承
}

\section{1.はじめに}

免震構造は免震層の水平剛性を上部構造に比べて小さくすること により，地震動による総入力エネルギーを免震層に集中させる損傷 制御構造である。積層ゴムと履歴減衰型ダンパーで構成される免震 構造では，エネルギーの釣合に基づく地震応答予測式から多ンパー 量の調整によるせん断力応答の低減効果が最大 $1 / 2$ 程度であること が示されており，また免震構造の最大の利点である応答低減効果は 建物周期を長周期化することにより，せん断応答の低減に帰せられ ることが明らかにされている1。さらに設計で採用される入力地震 動レベル（例えばレベル 2 地震動）では，ダンパーが降伏状態にあ る大変形時の建物周期（免震周期）を 4 秒以上にすると, 免震層の 最大変位が $25 \sim 35 \mathrm{~cm}$ の範囲に納まり，上部構造の応答せん断力係 数を0.1程度にできることが示されている(1),2。このような背景から 免震周期を長周期化する傾向があり，高面圧仕梯あるいは低せん断 弾性仕様の積層ゴムや，大変位時に弾性剛性を持たないすべり支承 や転がり支承と積層ゴムを併用することにより鉛直支持機構を形成 し; 免震周期の長周期化を実現している。

免震周期を長周期化する一つの方法として，鉛直支持機構である 積層ゴムと鉛直支持機構に加えて摩擦力を利用したエネルギー吸収 機構を兼ね備えた高摩擦型弾性すべり支承の二つの免震部材で免震.
層を構成するものがある。著者らは，このような免震構造に対して エネルギーの釣合に基づく地震応答予測式を提案している3)。この 中で提案している予測式を用いて，免震層が最小の応答せん断力を 示す時の樻層ゴムと弾性すべり支承の最適な割合を算出する手法を 提示するとともに，設計のプロセスを示した。減衰力を大きくする ために弾性すべり支承を過度に投入すると, 積層ゴムの減少に伴う て弾性剛性（復元力）が不足して, 免震層のエネルギ一吸収効率が 低下寸ることの危険性を提起している。また秋山は，せん断型多層 骨組の一般形を弾性要素 (柔要素) と弾塑性要素 (剛要素) の混合 構造である柔剛混合構造として捉え，剛要素に完全弾塑性型と剛性 劣化型 (Clough 型) の復元力特性を与えた地震応答解析を行い, 柔 要素と剛要素の割合が応答性状に与える影響を検証している4)。巢 要素と剛要素の負担せん断力比 $r_{q}$ を用いて, エネルギ一吸収効率 の指標である剛要素の累䄼塑性変形倍率と最大塑性変形倍率の比 $\eta / \mu_{m}$ と残留変形 $\delta_{r}$ を評価している。そしてエネルギー吸収性能を 向上させると同時に地震終了時の残留変形を小さく抑制するために は, 柔要素（弾性要素）の確保が重要なことを示している。

本研究では，積層ゴムと履歴減衰型ダンパーで構成される免震層 に加えて，専ら長周期化を四ることを目的とした低摩擦型すべり支 承を併用した 3 つの免震部材で構成される免震構造を対象としてエ
* 東京理科大学 大学院生

** 東京理科大学理工学部建築学科 助手. 博士 (工学)

*** 東京理科大学理工学部建築学科 教授 - 博士 (工学)
Graduate Student, Tokyo Univ. of Science

Research Assoc., Dept. of Architecture, Faculty of Science and Engineering, Tokyo Univ. of Science, Dr. Eng.

Prof., Dept. of Architecture, Faculty of Science and Engineering, Tokyo Univ. of Science, Dr. Eng. 
ネルギーの釣合に基づく応答予測式を導出する。そして数值解析を 行い，その数值解析結果から予測式の妥当性の検証を行う。また積 層ゴム (柔要素) とダンパー (剛要素) の負担せん断力比 $r_{q}$ を用い て，エネルギー吸収効率の指標である最大変形時におけるダンパー の等価履歴ループの繰返し数 $n_{1}$ と残留変形 $\delta_{r}$ を評価する。さら に，この予測式を用いて鉛直支持機構を構成する䅡層ゴムとすべり 支承の最適な割合を求める関係図を提示して，入力エネルギーの速 度換算值に応じたエネルギー吸収効率と少ない残留変形を保証する 低摩擦型すべり支承の負担する鉛直軸力の割合を決定するととも に，免震周期の長周期化が可能な範囲について検証する。最後に本 研究で奶象とする免震構造の設計法について要約する。

\section{2. 解析モデルと解析パラメータ}

本研究で対象とする積層ゴム・ダンパー及び低摩擦型すべり支承 で構成される免震構造の諸元を設定するとともに，本研究で対象と する免震建物の解析モデルの概要を述べる。

本研究で対象とする解析モデルを図 1 に示す。解析モデルは 5 質 点せん断振動系である。質量分布は各質点ともに等しく，剛性分布 は非免震時において最上層と最下層の割合が $1 / 2$ となる台形分布に 設定する。なお，建物周期は非免震時において 0.5 秒とする。減衰は 上部構造のみの一次固有円振動数 $\omega_{1}$ に対して $h=2 \%$ 部粘性 減衰 (減衰力 $\left.\{p\}=\sum_{j=1}^{N}\left(2 h / \omega_{1}\right)\left[k_{j}\right]\{\dot{x}\}\right)$ とする。またこのせん断系に 免震層を挿入した場合には, 第 1 層を剛性のみ変化させるとともに, 減衰はないものと設定する。また上部構造は弾性と仮定し，免震層 は各免震部材ごとに復元力を設定する。

積層ゴム，ダンパー及び低摩擦型すべり支承で構成される免震構 造の諸元を設定する。各免震部材の復元力特性を図 2 に示す。積層 ゴムの水平剛性を $k_{f}$, 負担する最大せん断力を ${ }_{f} Q_{\max }$, ダンパーの初 期水平剛性を $k_{s 1}$, 降伏酎力を $s_{1} Q_{y}$, 降伏変位を ${ }_{s 1} \delta_{y}$ とする。低摩擦 型すへり支承は完全弾塑性型の復元力特性を示すことから，ダン パーと同様に初期水平剛性を $k_{s 2}$, 摩擦力を降伏耐力 ${ }_{s 2} Q_{y}$, すべり開 始時の水平変位を $s 2 \delta_{y}$ と定義する。また，免震層における全せん断 力を $Q$, 最大水平変位を $\delta_{\max }$ とし, 地震動入力終了後 40 秒経過時の 水平変形を残留変形 $\delta_{r}$ と定義する。

建物全重量 $M g$ は，鉛直支持機構である積層ゴムと低摩擦型すへ り支承で鉛直面圧を等しく支持され，低摩擦型すべり支承で支持す る建物重量の割合を $R$ とする。この時の低摩擦型すべり支承の降伏

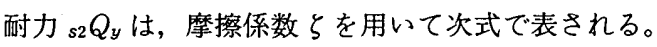

$$
{ }_{s 2} Q_{y}=\zeta R M g
$$

積層ゴムのせん断力係数 $\alpha_{f}$, ダンパーの降伏せん断力係数 $\alpha_{s}$ と，低摩擦型すべり支承の降伏せん断力係数 $\alpha_{s 2}$ を次式で定義する。

$$
\alpha_{f}=\frac{{ }^{f} Q_{\max }}{M g}, \quad \alpha_{s 1}=\frac{s_{1} Q_{y}}{M g}, \quad \alpha_{s 2}=\frac{s 2 Q_{y}}{M g}=\zeta R
$$

全て積層ゴムで支持した場合 $(R=0.0)$ の免震層の水平剛性を ${ }_{m} k_{f}$, 全て低摩擦型すべり支承で支持した場合 $(R=1.0)$ の免震層の 水平剛性を ${ }_{m} k_{s 2}$ とし, 式(3)に示すように ${ }_{m} k_{f}$ と $k_{s 1}$ の比率を ${ }_{m} r_{k s}$, ${ }_{m} k_{f}$ と ${ }_{m} k_{s 2}$ の比率 ${ }_{m} r_{k f}$ と定義する。

$$
{ }_{m} r_{k s}={ }_{m} k_{f} / k_{s 1}, \quad{ }_{m} r_{k f}={ }_{m} k_{f} /{ }_{m} k_{s 2}
$$

また, 積層ゴムの水平剛性 $k_{f}$, ダンパーの水平剛性 $k_{s 1}$, 低摩擦型 すべり支承の水平剛性 $k_{s 2}$ は，全て䅡層ゴムで支持した場合（ $R=$

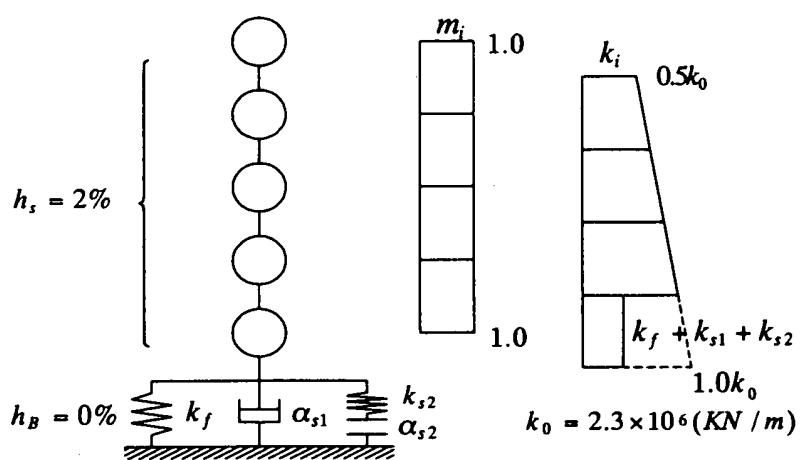

図 1 解析モデル

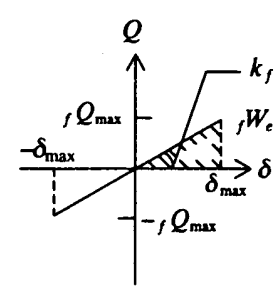

（a）積層コム

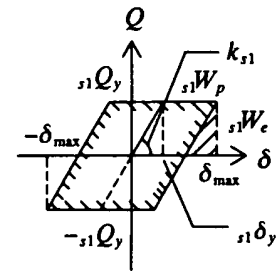

(b) ダンパー

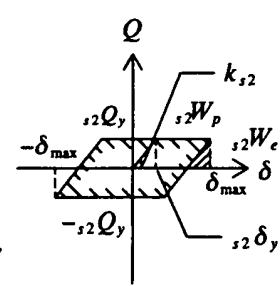

(c). 低摩擦型すべり支承

\begin{tabular}{|c|c|c|}
\hline 免震周期 $T_{1}(\mathrm{sec})$ & \multicolumn{2}{|l|}{$2.0,3 \cdot 0,4.0$} \\
\hline 摩擦係数 $\xi$ & \multicolumn{2}{|l|}{$0.01,0.05$} \\
\hline \multicolumn{2}{|c|}{ 積層ゴムとダンパーの用性比 ${ }_{m} r_{k s}$} & $0.1,0.2,0.5$ \\
\hline \multicolumn{2}{|c|}{ 積層コムとさずり支承の剛性比 ${ }_{m} r_{k f}$} & $0.05,0.10,0.20,0.50,1.00$ \\
\hline$R$ & \multicolumn{2}{|c|}{$0.0,0.1,0.2,0.3,0.4,0.5,0.6,0.7,0.8,0.9,1.0$} \\
\hline$\alpha_{s 1}$ & \multicolumn{2}{|c|}{$0.00,0.02,0.04,0.06,0.10$} \\
\hline
\end{tabular}

図 2 積層ゴム, ダンパー, 低摩擦型すべり支承の復元力特性

表 1 解析パラメータ

0.0）の免震周期 ${ }_{m} T_{f}$ を用いて次式のように表される。

$$
\begin{aligned}
& k_{f}=(1-R)_{m} k_{f}=\left(\frac{2 \pi}{{ }_{m} T_{f}}\right)^{2} \cdot M \cdot(1-R) \\
& k_{s 1}=\frac{m k_{f}}{{ }_{m} r_{k s}}=\left(\frac{2 \pi}{{ }_{m} T_{f}}\right)^{2} \cdot \frac{M}{{ }_{m} r_{k s}} \\
& k_{s 2}=R \cdot{ }_{m} k_{s 2}=\left(\frac{2 \pi}{{ }_{m} T_{f}}\right)^{2} \cdot \frac{M}{{ }_{m} r_{k f}} \cdot R \\
& { }_{m} T_{f}=2 \pi \sqrt{\frac{M}{{ }_{m} k_{f}}}, \quad T_{f}=2 \pi \sqrt{\frac{M}{k_{f}}}
\end{aligned}
$$

積層ゴムによる免震周期 $T_{f}$ と ${ }_{m} T_{f}$ は，式(4)，(7)より次式の関係 で示される。

$$
\frac{{ }_{m} T_{f}}{T_{f}}=\sqrt{\frac{k_{f}}{{ }_{m} k_{f}}}=\sqrt{1-R}
$$

せん断系に入力する地震動は，レべル 2 に相当する長周期領域で $S_{V}=100 \mathrm{~cm} / \mathrm{s}(h=5 \%)$ となる模擬地震動波形を用いる。基準法の 解放工学的基盤の加速度応答スペクトル形状を持つ模擬波形で, 採 用した位相特性 HACHINOHE $1968 \mathrm{EW，SENDAI} \mathrm{TH030} \mathrm{NS}$ .に対応し，今後それぞれを ART HACHI, ART TH030と呼ぶ。各 模擬波形の入力地震波継続時間を 82 秒, 解析時間増分を 0.01 秒とす る。なお残留変形を算出するため, それぞれの入力地震動に対して 原波終了時から 40 秒程度の間を $0 \mathrm{~cm} / \mathrm{sec}^{2}$ と入力している。

振動系を規定する解析パラメー夕を表 1 のように示す。全ての支 
承が積層ゴムの場合の免震周期 $m T_{f}$ を $2.0,3.0,4.0$ 秒に設定する。

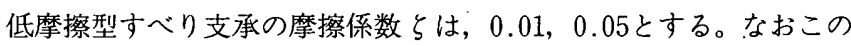
值は，現在一般に使用されているものの上下限值である。積層ゴム とダンパーの剛性比 ${ }_{m} r_{k s}$ を0.1, 0.2, 0.5, 積層ゴムと低摩擦型すへ $\eta$ 支承の剛性比 ${ }_{m} r_{k f}$ を0.05 1.00, すべり支承で支持する割合 $R$ を $0.0 \sim 1.0$, ダンパーの降伏せん断力係数 $\alpha_{s 1}$ を $0.00 \sim 0.10$ と設定 する。

\section{3. 免震部材のエネルギー配分}

\section{1 免震部材のエネルギー量の比較}

低摩擦型すべり支承を゙組み込んだ免震構造の応答予測をエネル ギーの釣合式に基づいて算出するにあたり，各免震部材の消費する エネルギー毎の入力エネルギーに占める割合について検討する。積 層ゴムの弾性歪エネルギーを ${ }_{f} W_{e}$, ダンパーの弾性歪エネルギーを ${ }_{s 1} W_{e}$, 履歴減衰エネルギーを $s 1 W_{p}$ とする。そして低摩擦型すべり支 承の弾性歪エネルギーを $s_{2} W_{e}$, 履歴減衰エネルギーを $s_{2} W_{p}$ とする。 $\alpha_{s 1}=0.02,0.04,0.06,0.10,{ }_{m} r_{k s}=0.1, \zeta=0.01,{ }_{m} r_{k f}=0.05$, 1.00 の振動系について, $R=0.0 \sim 1.0$ まで変化させ, 2 つの模擬波形 を用いて応答解析を行う。その応答解析結果より得られる各免震部 材が消費するエネルギーを入力エネルギーで除したものと低摩擦型 すべり支承の割合 $R$ の関係を図 3 に示す。なおそれぞれのエネル ギーは各応答解析結果での最大值を示している。図 $3(\mathrm{~b})$ から，常に 微小な值は $s_{1} W_{e}$ 及び $s_{2} W_{e}$ であり,これらの要素は，エネルギーの 釣合式において無視できる。

\section{2 等価繰返し数 $n_{1}$ の評価}

免震構造のエネルギーの釣合に基づく応答予測式を導出するにあ たって, 弾塑性要素のエネルギー吸収効率である等価繰返し数 $n_{1}$ について検証する。

等価繰返し数 $n_{1}$ は, 弾塑性要素が吸収する履歴減衰エネルギー を最大振幅時の 1 サイクルに描く履歴ループの何ループに相当する のかを示した数值であり, 最大塑性変形倍率 $\mu_{m}$ と累積塑性変形 $\delta_{p}$ 及び累積塑性変形倍率 $\eta$ を用いて，秋山により次式で表されてい $3^{4)}$ 。

$$
n_{1}=\eta / 4 \mu_{m}=\delta_{p} / 4\left(\delta_{\max }-\delta_{y}\right)
$$

${ }_{s 1} W_{e}$ 及び ${ }_{s 2} W_{e}$ は常に微小な值であるため, ダンパーの降伏変形 ${ }_{s 1} \delta_{y}$ と低摩摖型すべり支承のすべり始める時の変形 $s_{2} \delta_{y}$ がともに 微小な值であり無視できる。また，免震層は一体として挙動するの で，ダンパーと低摩擦型すべり支承の累積塑性変形 $\delta_{p}$ 及び最大水 平変形 $\delta_{\max }$ はともに同じ值となる。このことから式(9)で示される等 価繰返し数 $n_{1}$ は, ダンパーと低摩擦型すべり支承ともに同じ值を 示す。

積層ゴムとダンパー・低摩擦型すべり支承の負担せん断力比 $r_{q}$ は次式で表せる。

$$
r_{q}=\frac{{ }_{f} Q_{\max }}{{ }_{s 1} Q_{y}+{ }_{s 2} Q_{y}}
$$

秋山により,せん断型多層骨組みを対象とした構造種別において， 等価繰返し数 $n_{1}$ はせん断力比 $r_{q}$ との関係によって設計值を式(11) のように提示されている。

$$
\left.\begin{array}{ll}
r_{q}<1.0 の \text { 時 } & n_{1}=1.0+r_{q} \\
r_{q} \geq 1.0 の \text { 時 } & n_{1}=2.0
\end{array}\right\}
$$

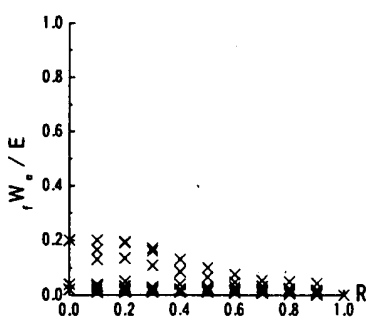

(a) ${ }_{f} W_{e} / E$

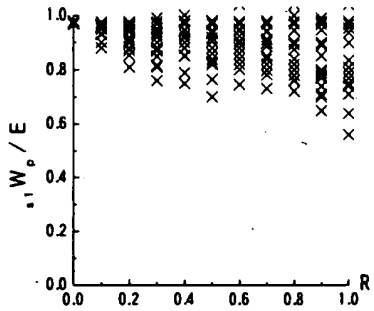

(c) ${ }_{s 1} W_{p} / E$

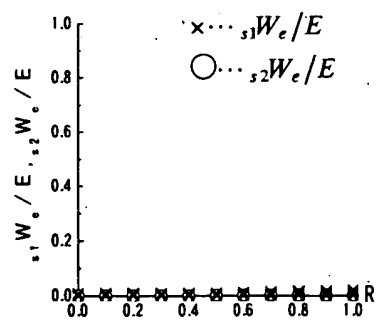

(b) ${ }_{s 1} W_{c} / E,{ }_{s 2} W_{c} / E$

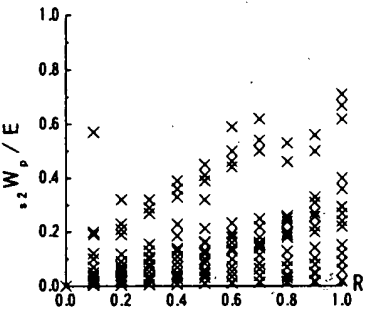

(d) ${ }_{s 2} W_{p} / E$
図 3 免震部材のエネルギー量

本研究の対象とする免震構造においても，式(11)により等価繰返し 数 $n_{1}$ を評価する。ここでは， $n_{1}$ は式(9)を簡便化して後述する応答予 測式に対応するように式(12)を用いて算出する。総入力エネルギーか ら最大水平変位発生時の積層ゴムの弾性歪エネルギーとの差を弾塑 性要素が消費する履歴減衰エネルギーとし，その履歴減衰エネル ギーをダンパーと低摩擦型すべり支承が最大水平変位発生時に描く 等価履歴ループの面積で除した值とする。なお $E,{ }_{f} Q_{\max }, \delta_{\max }$ は, 数值解析により得られた結果を用いる。

$$
n_{1}=\frac{2 E-{ }_{f} Q_{\max }: \delta_{\max }}{8_{s 1} Q_{y} \cdot \delta_{\max }+8_{s 2} Q_{y} \cdot \delta_{\max }}
$$

${ }_{m} T_{f}$ の違いにおける $n_{1}$ と $r_{q}$ の関係を図 $4(\mathrm{a}),(\mathrm{b}),(\mathrm{c}) に,{ }_{m} r_{k f}$ の 違いにおける $n_{1}$ と $r_{q}$ の関係を図 $4(\mathrm{~b}) ，(\mathrm{~d}) ，(\mathrm{e})$ に示す。さらに，入 力地震波の違いを図 4 (b), (f)に示す。シンボル記号で示された点は, $R=0.0 \sim 1.0$ の值を示し, $r_{q}=0.0$ の点は, 全ての支承が低摩擦型す べり支承の時 $(R=1.0)$ を表している。図 4 より，n1 つきを示すものの, 積層ゴムと低摩擦型すべり支承の剛性比 ${ }_{m} r_{k f}$ 及 び地震動波形の違いによらず， $n_{1}$ と $r_{q}$ は概ね正の相関関係にあり， 太実線で示された式(11)は，応答解析結果の下限值を概ね包絡してい る。このことから, 耐震構造の等価繰返し数 $n_{1}$ の評価式(11)は免震構 造でも準用できる。図 $4(\mathrm{a}),(\mathrm{b}),(\mathrm{c})$ より, 免震周期 $m T_{f}$ が長くなる と， $n_{1}$ は小さくなる傾向を示す。低摩擦型すべり支承の割合 $(R)$ の 変化とともに，積層ゴムの割合 $(1-R)$ も変化するため， $r_{q}$ は大き く変化するが, $r_{q} \geq 1.0$ を満たす範囲で低摩擦型すべり支承の割合を 増加させると，通常の免震構造のように $n_{1}=2.0$ を確保できる ${ }^{174)}$

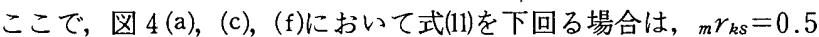
の時であり，ダンパーのエネルギー吸収効率が低下している状態で ある。その一例として図 5 に, ${ }_{m} T_{f}=4.0 \mathrm{~s},{ }_{m} r_{k f}=0.2, \zeta=0.01, \alpha_{s 1}=$ $0.10, R=0.2$ の時の ${ }_{m} r_{k s}$ の違いによるダンパーの履歴曲線を示す。 园 5 より, ダンパーの水平剛性 $k_{s 1}$ が積層ゴムの水平剛性 ${ }_{m} k_{f}$ に近 づくと，ダンパーは十分に塑性化されず弾性挙動を多く示すように なる。 


\section{4. エネルギーの釣合に基づく応答予測式の提案}

免震構造のエネルギーの釣合式は, 上部構造を剛体とみなし次式 のように表される。ここで $V_{E}$ は入力エネルギ一の速度換算值とす る。

$$
{ }_{f} W_{e}+{ }_{s 1} W_{e}+{ }_{s 1} W_{p}+{ }_{s 2} W_{e}+{ }_{s 2} W_{p}=E=M V_{E}^{2} / 2
$$

3.1 章より，s1 $W_{e}, s_{2} W_{e}$ は微小であるため無視すると，式(13)は次式 のように簡略できる。

$$
{ }_{f} W_{e}+{ }_{s 1} W_{p}+{ }_{s 2} W_{p}=M V_{E}^{2} / 2
$$

従って，エネルギ一の釣合式(14)から応答予測式を算出する。

$0.0 \leq R<1.0$ の時, 基準となる応答量として, 無減衰時のせん断力 係数 $\alpha_{0}$, 免震層の水平変位 $\delta_{0}$ を次式で定義する。

$$
\alpha_{0}=\frac{2 \pi V_{E}}{T_{f} \cdot g}, \quad \delta_{0}=\frac{T_{f} \cdot V_{E}}{2 \pi}
$$

積層ゴムの弾性歪エネルギー ${ }_{f} W_{e}$ は，次式のように表せる。

$$
{ }_{f} W_{e}=\frac{1}{2}, Q_{\max } \cdot \delta_{\max }=\left(\frac{\alpha_{f}}{\alpha_{0}}\right)^{2} \cdot \frac{M V_{E}^{2}}{2}
$$

ダンパーの履歴減衰エネルギー ${ }_{s 1} W_{p}$ は次式のように表せる。な お， $s_{1} W_{e}$ が微小であることから ${ }_{s 1} \delta_{y} \cong 0$ とする。

$$
\begin{aligned}
s_{1} W_{p} & =4 n_{1} \cdot{ }_{s 1} Q_{y} \cdot\left(\delta_{\max }-{ }_{s 1} \delta_{y}\right) \\
& =8 n_{1}\left(\frac{\alpha_{f}}{\alpha_{0}}\right)\left(\frac{\alpha_{s 1}}{\alpha_{0}}\right) \cdot \frac{M V_{E}{ }^{2}}{2}
\end{aligned}
$$

低摩擦型すべり支承の摩擦力による履歴減衰エネルギー ${ }_{s 2} W_{p}$ は 次式で表せる。なお， ${ }_{s 2} W_{e}$ が微小であることから ${ }_{s 2} \delta_{y} \cong 0$ とする。

$$
\begin{aligned}
{ }_{s 2} W_{p} & =4 n_{1} \cdot s 2 Q_{y} \cdot\left(\delta_{\max }-{ }_{s 2} \delta_{y}\right) \\
& =8 n_{1}\left(\frac{\alpha_{f}}{\alpha_{0}}\right)\left(\frac{\alpha_{s 2}}{\alpha_{0}}\right) \cdot \frac{M V_{E}{ }^{2}}{2}
\end{aligned}
$$

式(14)に式(16)，(17)，(18)を代大すると，式(19)が求まる。

$$
\left(\frac{\alpha_{f}}{\alpha_{0}}\right)^{2}+8 n_{1}\left(\frac{\alpha_{s 1}+\alpha_{s 2}}{\alpha_{0}}\right)\left(\frac{\alpha_{f}}{\alpha_{0}}\right)=1
$$

式(19)より，積層ゴムのせん断力係数 $\alpha_{f}$ は次式のように求まる。

$$
\frac{\alpha_{f}}{\alpha_{0}}=-4 n_{1}\left(\frac{\alpha_{s 1}+\alpha_{s 2}}{\alpha_{0}}\right)+\sqrt{16 n_{1}^{2}\left(\frac{\alpha_{s 1}+\alpha_{s 2}}{\alpha_{0}}\right)^{2}+1}
$$

式(20)より，免震層の全せん断力係数 $\alpha_{1}$ は次式のように求まる。

$$
\begin{aligned}
\frac{\alpha_{1}}{\alpha_{0}} & =\frac{\alpha_{f}}{\alpha_{0}}+\frac{\alpha_{s 1}}{\alpha_{0}}+\frac{\alpha_{s 2}}{\alpha_{0}} \\
& =-\left(4 n_{1}-1\right)\left(\frac{\alpha_{s 1}+\alpha_{s 2}}{\alpha_{0}}\right)+\sqrt{16 n_{1}^{2}\left(\frac{\alpha_{s 1}+\alpha_{s 2}}{\alpha_{0}}\right)^{2}+1}
\end{aligned}
$$

免震層の最大水平変位 $\delta_{\max }$ は， $\alpha_{f}$ を用いて次式のように表せる。

$$
\begin{aligned}
& \delta_{\max }=\frac{\rho_{\max }}{k_{f}}=\frac{\alpha_{f} g}{(1-R)}\left(\frac{m T_{f}}{2 \pi}\right)^{2}=\frac{\alpha_{f} \cdot \delta_{0}}{\alpha_{0}} \\
& \frac{\delta_{\max }}{\delta_{0}}=\frac{\alpha_{f}}{\alpha_{0}}=-4 n_{1}\left(\frac{\alpha_{s 1}+\alpha_{s 2}}{\alpha_{0}}\right)+\sqrt{16 n_{1}^{2}\left(\frac{\alpha_{s 1}+\alpha_{s 2}}{\alpha_{0}}\right)^{2}+1}
\end{aligned}
$$

式(21)，(23)は弾塑性要素の量を変数として $\alpha_{1}$ と $\delta_{\max }$ の予測值を求 めているので，文献1)で提案されている㴊要素をダンパーのみとし た通常の免震構造の予測式と類似したものとなっている。なお，低 摩擦型すべり支承がない場合 $(R=0.0)$ では, 式(2)より $\alpha_{s 2}=0.0$ と なることから通常の免震構造の応答子測式と一致したものとなって いる。

式(19)に式(22)を代入し， $\alpha_{s 1}+\alpha_{s 2}$ と $\delta_{\max }$ の関係を求めると次式のよ うになる。
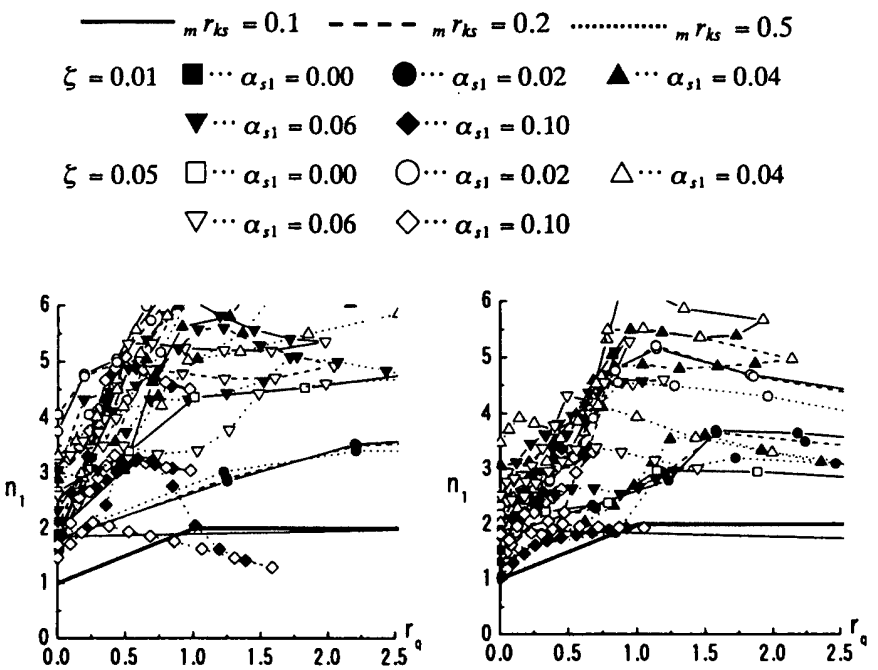

(a) ${ }_{m} T_{f}=2.0 s,{ }_{m} r_{t g}=0.2$ ART HACHI

(b) ${ }_{m} T_{f}=3.0 s,{ }_{m} r_{\mathrm{kf}}=0.2$ ART HACHI
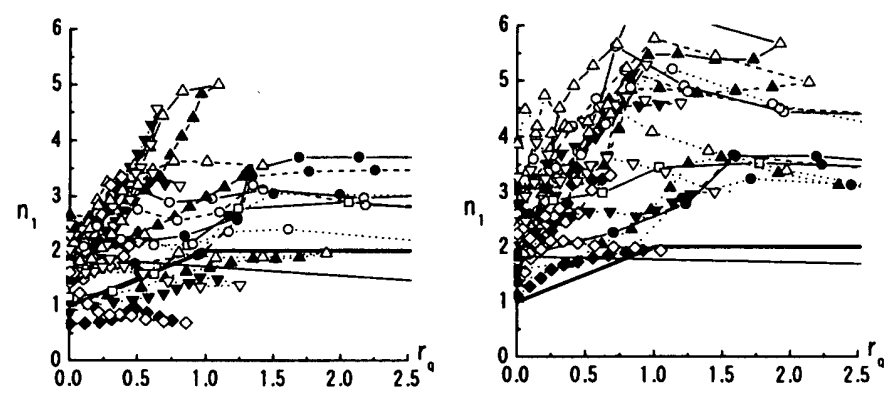

(c) ${ }_{m} T_{f}=4.0 s,{ }_{m} r_{k f}=0.2$ ART HACHI

(d) ${ }_{m} T_{f}=3.0 \mathrm{~s},{ }_{m} r_{\text {kf }}=0.05$ ART HACHI
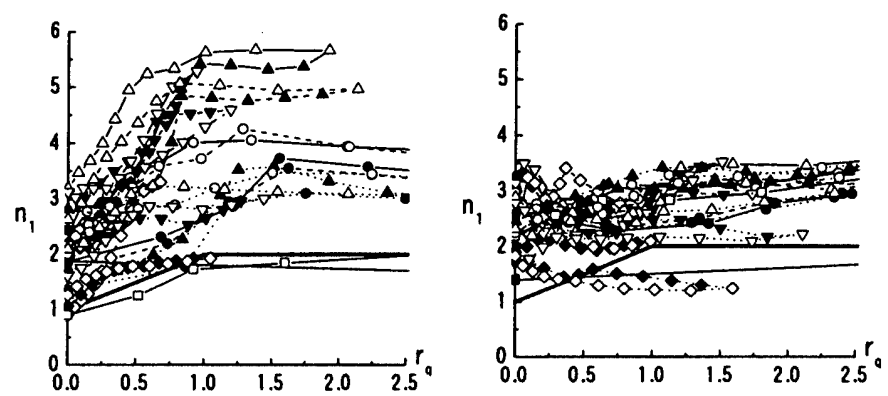

(e) ${ }_{m} T_{f}=3.0 \mathrm{~s},{ }_{m} r_{\text {ty }}=0.5$ ART HACHI

(f) ${ }_{m} T_{f}=3.0 s,{ }_{m} r_{k f}=0.2$ ART TH030

図4 $n_{1}$ と $r_{q}$ の関係

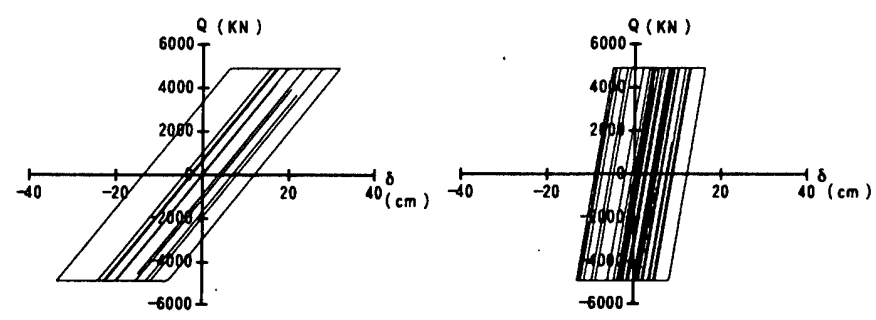

(a) ${ }_{m} r_{b s}=0.5$

(b) ${ }_{m} r_{k}=0.1$ 


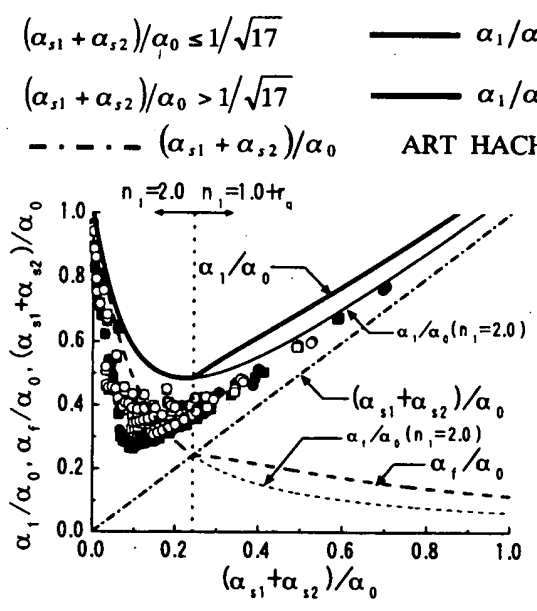

(a) ${ }_{n} T_{f}=2.0 s, 5-0.01$

$$
\begin{aligned}
& \alpha_{1} / \alpha_{0}\left(n_{1}=2.0\right)--\alpha_{f} / \alpha_{0}\left(n_{1}=2.0\right) \\
& \alpha_{1} / \alpha_{0}\left(n_{1}=1+r_{q}\right)--\alpha_{f} / \alpha_{0}\left(n_{1}=1+r_{q}\right)
\end{aligned}
$$$$
\alpha_{1} / \alpha_{0}\left(n_{1}=2.0\right)
$$$$
-\ldots \alpha_{f} / \alpha_{0}\left(n_{1}=2.0\right)
$$

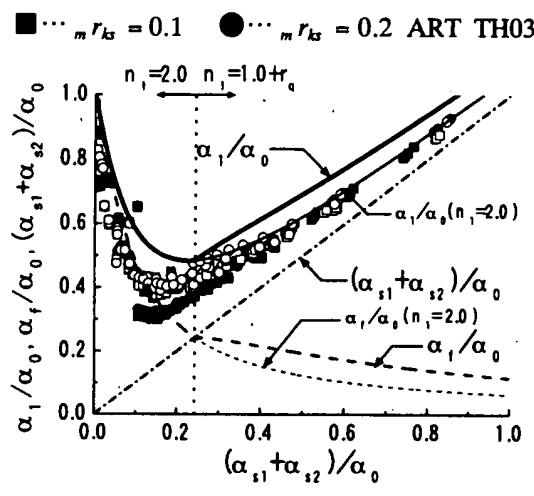

(b) ${ }_{m} T_{f}-3.0 s, \zeta-0.01$

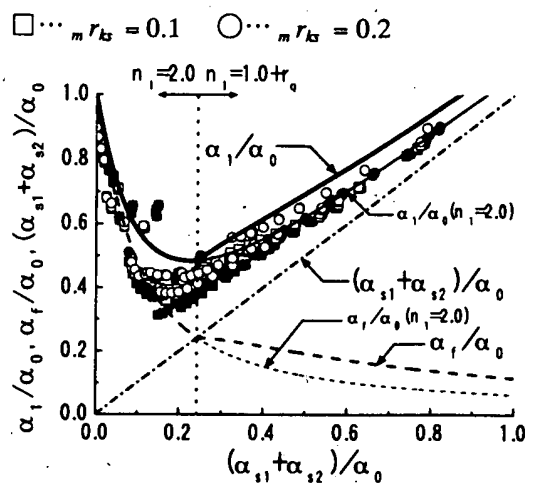

(c) ${ }_{m} T_{f}=4.0 s, 5=0.01$

図 $6 \quad \alpha_{1} / \alpha_{0}$ と $\left(\alpha_{s 1}+\alpha_{s 2}\right) / \alpha_{0}$ の関係

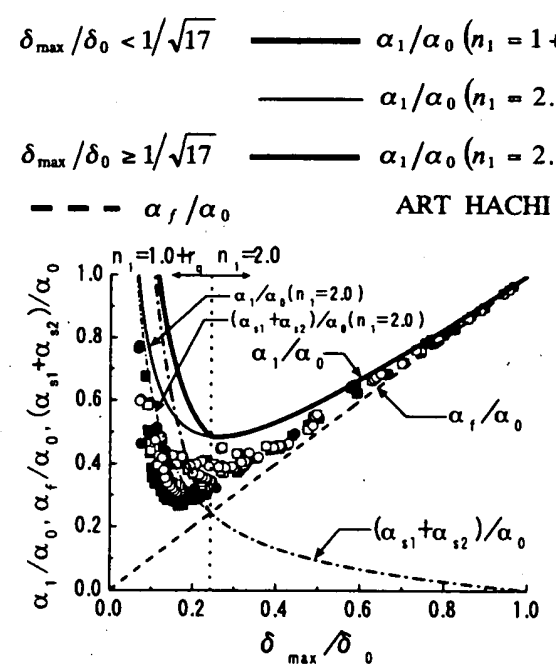

(a) ${ }_{n} T_{f}=2.0 s, \zeta=0.01$

$$
\begin{aligned}
& \left.+r_{q}\right)-\cdots-\left(\alpha_{s 1}+\alpha_{s 2}\right) / \alpha_{0}\left(n_{1}=1+r_{q}\right) \\
& 2.0) \quad \cdots-\left(\alpha_{s 1}+\alpha_{s 2}\right) / \alpha_{0}\left(n_{1}=2.0\right) \\
& -0)-\left(\alpha_{s 1}+\alpha_{s 2}\right) / \alpha_{0}\left(n_{1}=2.0\right)
\end{aligned}
$$

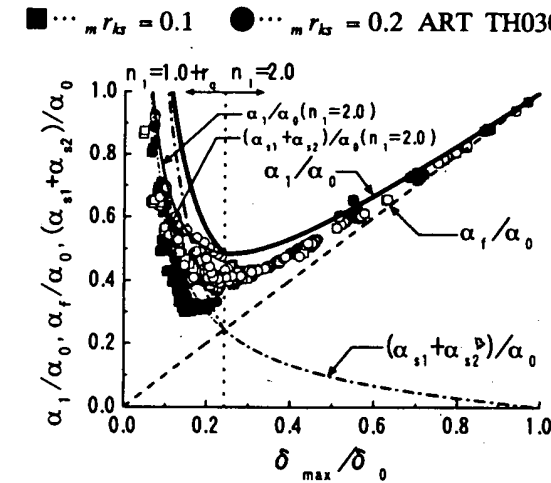

(b) ${ }_{m} T_{f}=3.0 s, \zeta=0.01$

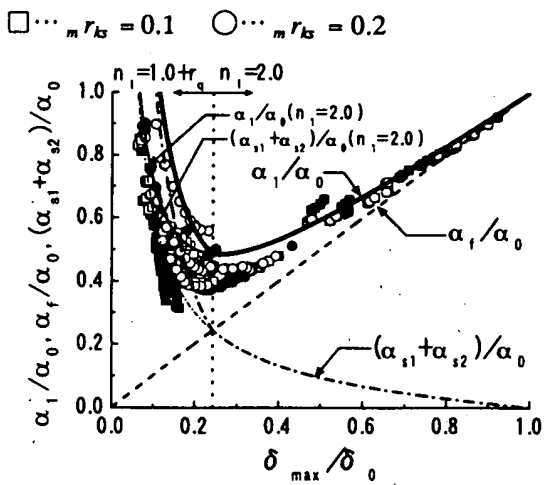

(c) ${ }_{m} T_{f}=4.0 s, \zeta=0.01$

园 $7 \alpha_{1} / \alpha_{0}$ と $\delta_{\max } / \delta_{0}$ の関係

$$
\frac{\alpha_{s 1}+\alpha_{s 2}}{\alpha_{0}}=\frac{1}{8 n_{1}}\left\{\left(\frac{\delta_{0}}{\delta_{\max }}\right)-\left(\frac{\delta_{\max }}{\delta_{0}}\right)\right\}
$$

また，式(24)を式(21)に代入すると， $\alpha_{1}$ と $\delta_{\max }$ の関係が次式のように 求まる。

$$
\frac{\alpha_{1}}{\alpha_{0}}=\frac{1}{8 n_{1}}\left\{\left(\frac{\delta_{0}}{\delta_{\max }}\right)+\left(8 n_{1}-1\right)\left(\frac{\delta_{\max }}{\delta_{0}}\right)\right\}
$$

式(25)は，通常の免震構造における $\alpha_{1}$ と $\delta_{\max }$ の関係と一致するこ とから ${ }^{2)}, \alpha_{1}$ の最小值 $\alpha_{1 \min }$ を求めると次式で表せる。

$$
\begin{aligned}
& \delta_{\max }\left(\alpha_{1 \min }\right)=\frac{\dot{\delta}_{0}}{\sqrt{15}} \\
& \alpha_{1 \mathrm{~m} \ln }=\frac{\sqrt{15}}{8} \cdot \alpha_{0} \\
& \alpha_{f}\left(\alpha_{1 \mathrm{~m} ! n}\right)=\frac{\alpha_{0}}{\sqrt{15}}, \quad\left(\alpha_{s 1}+\alpha_{s 2}\right)\left(\alpha_{1 \mathrm{~m} ! n}\right)=\frac{7 \alpha_{0}}{8 \sqrt{15}}
\end{aligned}
$$

式(10), (28)より, 弾性要素と弾塑性要素のせん断力比 $r_{q}$ が $8 / 7$ 時に $\alpha_{1}$ は最小值となる。なお今後本研究では，簡便な值を用いて指標を 提示するために $\alpha_{1}$ が最小值となる時のせん断力比 $r_{q}$ は 1.0 として
扱う。式(27)から求める $\alpha_{1 \mathrm{~m} \ln }$ と後述する式(32)加求まる $\alpha_{1}\left(r_{q}=1.0\right)$ を比較すると， $\alpha_{1}\left(r_{q}=1.0\right)$ のほうがわずかに大きめな安全側の值で ある。

なお $R=1.0$ の時, 鉛直荷重は低摩擦型すべり支承のみで支持し ている場合には，免震層は耐震構造の応答予測式を適用すれば良 (4)。

\section{5. 数值解析に基づく検証}

\section{1 応答予測式の検証}

本研究で提案している応答予測式により時刻歴応答解析から得ら れる解析結果の評価を行い, 応答予測式(21)，(25)の妥当性を検証する。 なお応答予測式(21)，(25)を決定するために必要な等価繰返し数 $n_{1}$ は 式(11)から算出している。

図 6 に ${ }_{m} T_{f}$ の違いによる免震層の応答せん断力係数 $\alpha_{1} / \alpha_{0}$ と剛 要素のせん断力係数 $\left(\alpha_{s 1}+\alpha_{s 2}\right) / \alpha_{0}$ の関係を示し, さらに, 図 7 に ${ }_{m} T_{f}$ の違いによる $\alpha_{1} / \alpha_{0}$ と免震層の最大水平変位 $\delta_{\max } / \delta_{0}$ の関係を 示す。二つの図中に示す太実線, 太破線, 太一点鎖線はそれぞれ 
$\alpha_{1} / \alpha_{0}, \alpha_{f} / \alpha_{0},\left(\alpha_{s 1}+\alpha_{s 2}\right) / \alpha_{0}$ を表している。また, 応答予測式の等価 繰返し数 $n_{1}$ を算出するのに式(11)を用いずに， $r_{q}<1.00$ 範囲（図 6 では $\left(\alpha_{s 1}+\alpha_{s 2}\right) / \alpha_{0}>1 / \sqrt{17}$, 図 7 では $\left.\delta_{\max } / \delta_{0}<1 / \sqrt{17}\right)$ で, すべて $n_{1}=2.0$ として算出した $\alpha_{1} / \alpha_{0}, \alpha_{f} / \alpha_{0},\left(\alpha_{s 1}+\alpha_{s 2}\right) / \alpha_{0}$ をそれぞれ細実 線, 細破線, 細一点鎖線で表している。図 6,7 より, 予測式は概 ね解析結果の上限值を包絡する值である。 $r_{q}<1.0$ の範囲で, 細実線 $\left(n_{1}=2.0\right)$ で示された $\alpha_{1} / \alpha_{0}$.の予測值に比べ応答值の方が上回るが, 太実線 $\left(n_{1}=1+r_{q}\right)$ で示された予測值の方が安全側に評価できるこ とを示している。

\section{2 残留変形 $\boldsymbol{\delta}_{r}$ の検証}

残留変形 $\delta_{r}$ は，地震終了時における建築物の修復の難易度を支 配する值である。文献4)は，柔剛混合構造において剛要素の復元力 特性を完全弾塑性型とした場合の残留変形 $\delta_{r}$ をせん断力比 $r_{q}$ を 用いて評洒し， $r_{q}$ の増大によって残留変形 $\delta_{r}$ が抑制されることを 示している。免震構造では低摩擦型すべり支承を挿入する量が増す に従い，積層ゴムの負担せん断力が減少しせん断力比 $r_{q}$ が小さく なる。つまり低摩擦型すべり支承の量を増やし過ぎると残留変形 $\delta_{r}$ が大きくなる可能性がある。そこで本研究は, せん断力比 $r_{q}$ を用い て残留変形 $\delta_{r}$ を評価し, 低摩擦型すべり支承の設置量の上限值を 求める。

文献4)より, 残留変形倍率 $\Delta \eta$ と最大塑性変形倍率 $\mu_{m}$ の比率は 次のように表せる。

$$
\frac{\Delta \eta}{\mu_{m}}=\frac{\delta_{r}}{\delta_{\max }-\delta_{y}}
$$

ここで, $\Delta \eta=\delta_{r} / \delta_{y}, \quad \mu_{m}=\left(\delta_{\max }-\delta_{y}\right) / \delta_{y}$

ダンパーの降伏変形 $s 1 \delta_{y}$ と低摩擦型すべり支承のすべり始める 時の変形 ${ }_{22} \delta_{y}$ がともに微小な值であるため, 式(29)より残留変形 $\delta_{r}$ を最大水平変位 $\delta_{\max }$ との比率で評価する。

秋山により,多質点せん断振動系において, 残留変形 $\delta_{r}$ を最大塑 性変形倍率と残留変形倍率の比率で表し, せん断力比 $r_{q}$ で評価し ている。本研究では, 最大水平変位 $\delta_{\max }$ と残留変形 $\delta_{r}$ の比率とす る。多質点せん断振動系において提示されている上限值は，次のよ うに表される。

$$
\left.\begin{array}{ll}
r_{q}<0.5 \text { の時 } & \delta_{r} / \delta_{\max }=1 / 1+3 r_{q} \\
r_{q} \geq 0.5 \text { の時 } & \delta_{r} / \delta_{\max }=0.4
\end{array}\right\}
$$

式(30)で表される $\delta_{r}$ は上限值を規定しており，平均的な值として 概ね半分程度を想定している4)。

${ }_{m} T_{f}$ の違いによる $\delta_{r} と r_{q}$ の関係を図 $8(\mathrm{a}),(\mathrm{b}),(\mathrm{c})$ に,${ }_{m} r_{k f}$ の違 いによる $\delta_{r}$ と $r_{q}$ の関係を図 $8(\mathrm{~b}),(\mathrm{d}),(\mathrm{e})$ に示す。さらに, 入力地 震波の違いによる $\delta_{r}$ と $r_{q}$ の関係を図 $8(\mathrm{~b})$ ，(f)に示す。図 8 から $r_{q}$ の增加に伴い, 最大水平変位 $\delta_{\max }$ に対する残留変形 $\delta_{r}$ の割合が減 少するものの， $r_{q}$ が一定以上になると $\delta_{r} / \delta_{\max }$ は収束する傾向にあ る。また太実線で示している式(30)は，解析値の上限值を概ね包絡し ている。なお, $\delta_{r} / \delta_{\max }$ に对する免震周期 ${ }_{m} T_{f}$, 剛性比 ${ }_{m} r_{k f}$ の影響は みられない。耐震構造の残留変形 $\delta_{r}$ の評価式として提示されてい る式(30)は免震構造でも準用できる。残留変形 $\delta r$ を抑之るための低 摩擦型すべり支承の上限值は, 最大水平変位 $\delta_{\max }$ に対する残留変形 $\delta_{r}$ の比率が $0.4 に$ 抑えられている $r_{q} \geq 0.5$ の範囲である。

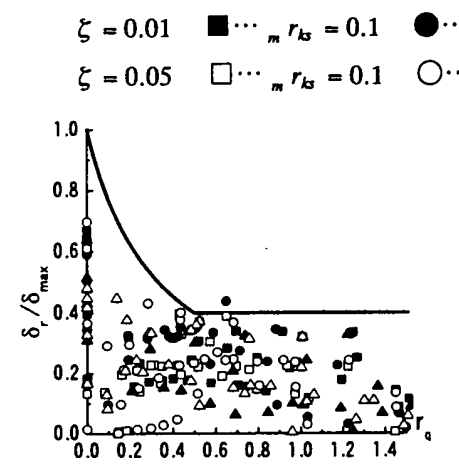

(a) ${ }_{m} T_{f}=2.0 s,{ }_{m} r_{k f}=0.2$ ART HACHI

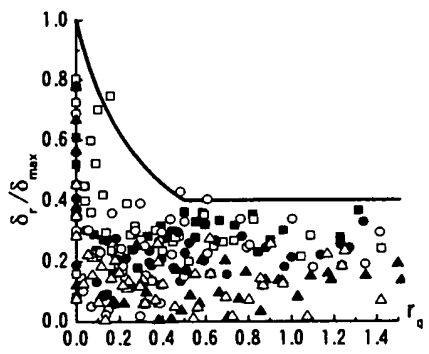

(c) ${ }_{m} T_{f}=4.0 s,{ }_{m} r_{\text {lf }}=0.2$ ART HACHI
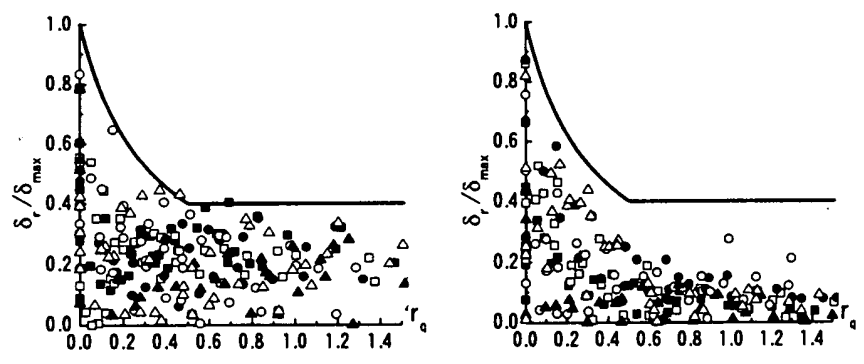

(e) ${ }_{m} T_{f}=3.0 s,{ }_{m} r_{k f}=0.5$ ART HACHI ART TH030 (f) ${ }_{m} T_{f}=3.0 s,{ }_{m} r_{k f}=0.2$

図 $8 \delta_{r} / \delta_{\max }$ と $r_{q}$ の関係

\section{6．低摩擦型すへり支承を組合せた免震構造の可能性}

本研究で対象とする低摩擦型すべり支承を組合せた免震構造が安 定した応答性状を維持するために要求される諸元を応答予測式から 導出した。これらの結果から，設計目標を定める関係図を提示する。 そして低摩擦型すべり支承を組合せた免震構造の免震周期 $T_{f}$ の長 周期化が可能な範囲について検証を行う。

式(2)，(10)より， $r_{q}=1.0 の$ 時の免震層の全せん断力係数 $\alpha_{1}\left(r_{q}=\right.$ 1.0) と積層ゴム, ダンパー及び低摩擦型すべり支承のせん断力係数 $\alpha_{f}, \alpha_{s 1}, \alpha_{s 2}$ の関係は次式で表される。

$$
\alpha_{1}\left(r_{q}=1.0\right)=2 \alpha_{f}=2\left(\alpha_{s 1}+\alpha_{s 2}\right) \text {. }
$$

式(11)，(15)，(21)，(31)より， $r_{q}=1.0$ の時の免震層の全せん断力係数 $\alpha_{1}$ $\left(r_{q}=1.0\right)$ は $V_{E}, T_{f}$ を用いて次式で表される。

$$
\alpha_{1}\left(r_{q}=1.0\right)=\frac{2}{\sqrt{17}} \cdot \frac{2 \pi V_{E}}{T_{f} g}=\frac{2}{\sqrt{17}} \alpha_{0}
$$

また，式(8)，(32)より $\alpha_{1}\left(r_{q}=1.0\right)$ と $R$ の関係は， $V_{E},{ }_{m} T_{f}$ を用い て次式で表される。 


$$
\alpha_{1}\left(r_{q}=1.0\right)=2 \sqrt{\frac{1-R}{17}} \cdot \frac{2 \pi V_{E}}{m T_{f} g}
$$

式(15)，(22)，(31)，(32)より $\delta_{\max }$ を用いて $T_{f}$ と $V_{E}$ の関係は次式のよう に求まる。

$$
V_{E}=\sqrt{17} \cdot \frac{2 \pi \delta_{\max }\left(r_{q}=1.0\right)}{T_{f}}
$$

式(32)より $\alpha_{1}\left(r_{q}=1.0\right)$ を用いて $T_{f}$ と $V_{E}$ の関係が次式で表せる。

$$
V_{E}=\frac{\sqrt{17} \cdot g \cdot \alpha_{1}\left(r_{q}=1.0\right)}{4 \pi} \cdot T_{f}
$$

さらに, 式(8)，(32)，(34)より， $\delta_{\max }$ を用いて $\alpha_{1}\left(r_{q}=1.0\right)$ と $R$ の関 係は次式で表せる。

$$
\alpha_{1}\left(r_{q}=1.0\right)=\frac{2}{g} \cdot\left(\frac{2 \pi}{m T_{f}}\right)^{2} \cdot(1-R) \cdot \delta_{\max }\left(r_{q}=1.0\right)
$$

式(34)より, $r_{q} \geq 1.0$ を満たす免震周期 $T_{f}$ の範囲は設計用入力地震 動レベル $V_{E}$ と目標最大水平変位 $\delta_{\max }$ を用いて次式で表せる。

$$
T_{f} \leq \sqrt{17} \frac{2 \pi}{V_{E}} \delta_{\max }
$$

式(34)，(35)から得られる設計用入力地震動レベル $V_{E}$ に応じた免震 周期 $T_{f}$ との関係を免震層の全せん断力係数 $\alpha_{1}\left(r_{q}=1.0\right)$ 及び最大 水平変位 $\delta_{\max }\left(r_{q}=1.0\right)$ を用いて図 9 に示す。図中の細実線は全せ ん断力係数 $\alpha_{1}$ を $\alpha_{1}\left(r_{q}=1.0\right)=0.05 \sim 0.40$ の範囲で示し, 太実線は 最大水平変位 $\delta_{\max }$ を $\delta_{\max }=20 \sim 80 \mathrm{~cm}$ の範囲で示す。設計する際に 入力地震動レベル. $V_{E}$ と最大水平変位 $\delta_{\max }$ を設定し, その時の免震 周期 $T_{f}$ と免震層の全せん断力倸数 $\alpha_{1}$ の值が求められる。例之ば,

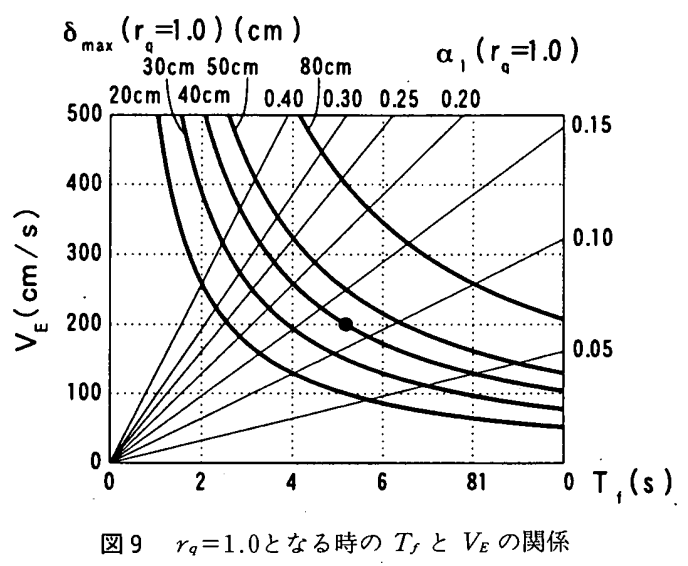

図中の○印で示す $V_{E}=200 \mathrm{~cm} / \mathrm{sec}$, 目標最大水平変位 $\delta_{\max }=40 \mathrm{~cm}$ と設定する場合では, 免震周期 $T_{f}$, 免震層の全せん断力係数 $\alpha_{1}$ は, それぞれ $5.18 \mathrm{~s}, 0.12$ となる。この $T_{f}$ の值は，工ネルギー吸収効率 を低下させず，少ない残留変形 $\delta_{r}$.を保証する免震周期の限界值を 示している。

設計用入力地震動レベル $V_{E}$ と目標最大水平変位 $\delta_{\max }\left(r_{q}=1.0\right)$ 及びダンパーの降伏せん断力係数 $\alpha_{s 1}\left(r_{q}=1.0\right)$ を用いて $\alpha_{1}\left(r_{q}=\right.$ 1.0）とR の関係を ${ }_{m} T_{f}$ 毎に図10に示す。なお図中に $V_{E}$ のレベル を太実線， $\delta_{\max }\left(r_{q}=1.0\right)$ を細実線， $\alpha_{s 1}\left(r_{q}=1.0\right)$ を破線， $T_{f}$ を点 線で表す。なお， $r_{q}=1.0$ を条件としているため $R=1.0$ は存在せず, 罒中〉印で表す。図 9 から免震周期 $T_{f}$ の上限值が決定されると, 式

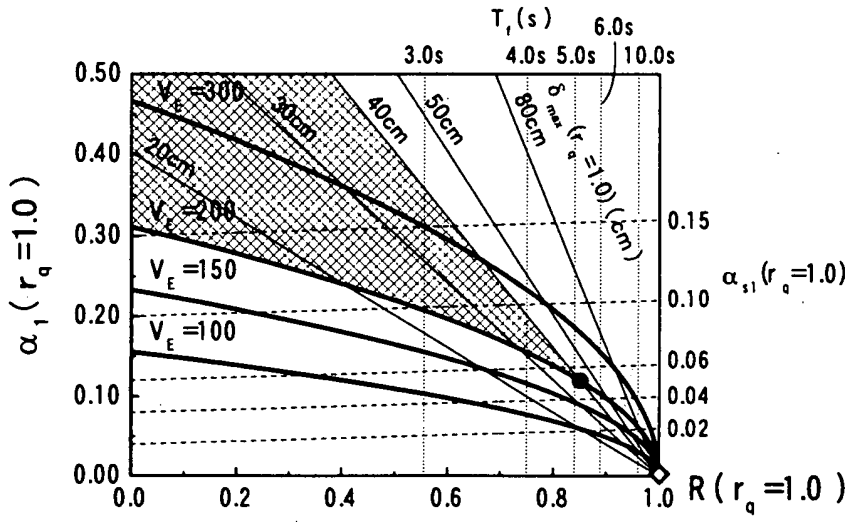

(a) ${ }_{m} T_{f}=2.0 \mathrm{~s}, \zeta=0.01$

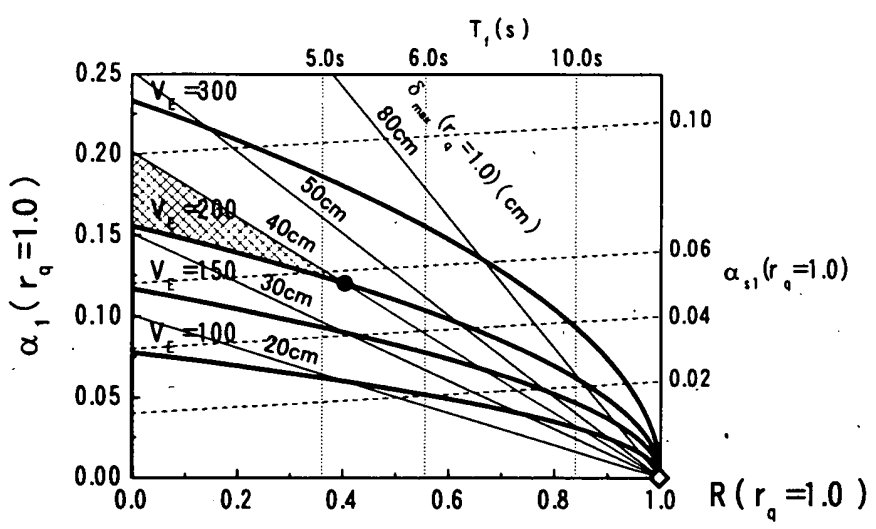

(c) ${ }_{m} T_{f}=4.0 \mathrm{~s}, \zeta=0.01$

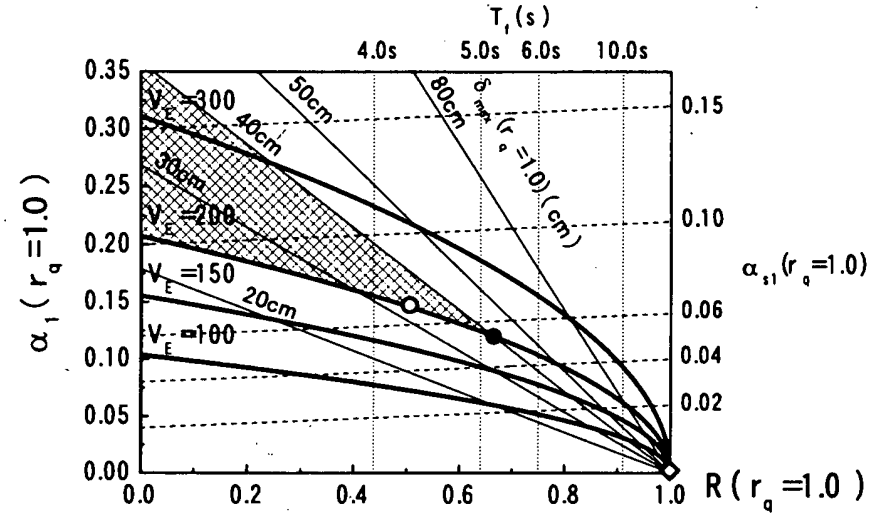

(b) ${ }_{m} T_{f}=3.0 s, \zeta=0.01$

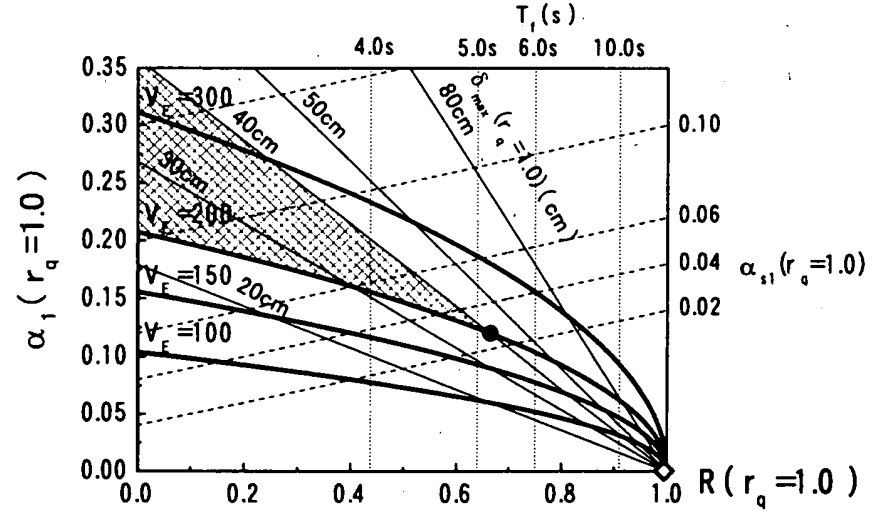

(d) ${ }_{m} T_{f}=3.0 \mathrm{~s}, \zeta=0.05$ 
(8)を用いて全ての鉛直力を積層ゴムで支持した場合の免震周期 ${ }_{m} T_{f}$ に応じた低摩擦型すべり支承の割合 $R$ とダンパー量 $\left(\alpha_{s 1}\right)$ が求ま $\eta$ ，この時に示す值が低摩擦型すべり支承の設置限界量となる。例 えば, 図 9 と同様の条件 $V_{E}=200 \mathrm{~cm} / \mathrm{sec}, \delta_{\max }=40 \mathrm{~cm}$ で設定する場 合では, 図 9 より免震周期 $T_{f}$ が5.18sになることから, 図10(b)のよ jに ${ }_{m} T_{f}=3.0 \mathrm{~s}, \zeta=0.01$ とすると, $R=0.66, \alpha_{s 1}\left(r_{q}=1.0\right)=0.054$ と求まる。しかし図10より得られる低摩擦型すべり支承の割合 $R$ は 設置限界量である。設計用入力地震動レベル以上の地震動が免震層 に入力された場合, 設計の際に設定した最大水平変位以上の変位が 生し，その結果上部構造に影響を及ばす恐れがある。網掛けは， $V_{E}=$ $200 \mathrm{~cm} / \mathrm{sec}$ 以上で $\delta_{\max }=40 \mathrm{~cm}$ 以下の範囲を示す。この図から明ら かなように，の印で表した $R$ の上限值より下回るような で設定すれば， $\alpha_{1}$ は増加するものの， $\delta_{\max }$ は $V_{E}$ が増大しても確保 できる。

\section{7 . 低摩擦型すへり支承を組み込んだ免震構造の設計法の要約}

免震構造の設計は，積層ゴムとダンパーから構成される免震層で 基本的な構造計画を立案し，積極的に免震周期を長周期化したい場 合，柱軸力が小さいために積層ゴムの性能が十分発揮できない場合 に低摩擦型すべり支承が適用される。低摩擦型すべり支承は摩擦力 が小さいために直ちにすべり状態となるので, 弾性要素（柔要素） の水平剛性は積層ゴムのみの水平剛性で与えて免震周期 $T_{f}$ を算定 する。また低摩擦型すべり支承の履歴減衰エネルギーが無視できな いため,ダンパーとともに弾塑性要素に含ませる。そして積極的に 低摩擦型すべり支承を組み込んで免震周期を長くした場合には，積 層ゴムを減らした影響により免震構造が安定した応答性状を維持で きるのか重要となる。なお，低摩擦型すべり支承のすべり状態時の 㨭れ振動や，個々のすべり支承の摩擦力の変動による㨝れ振動は， 別途解決されているものとする。また，上部構造が剛体とみなせる （超高層免震は適用不可）ものとする。

これらの条件のもとに導かれたエネルギーの釣合に基づく応答予 測式から，低摩擦型すべり支承を適用する免震構造の免震部材に関 わる設計法を以下のように要約できる。

1）免震構造として安定した応答性状を表す指標として等価繰返し 数 $n_{1}$ と残留変形 $\delta_{r}$ に着目し，秋山により耐震構造で提案された $n_{1}$ および $\delta_{r}$ と負担せん断力比 $r_{q}$ との関係式)が本研究で対象と している免震構造にも適用できることを示した。等価繰返し数 $n_{1}$ 22.0 を確保するためには, 積層ゴムに免震層のせん断力の半分以 上 $\left(r_{q} \geq 1.0\right)$ を負担させ，また残留変形 $\delta_{r} / \delta_{\max } \leq 0.4$ を確保する ためには $r_{q} \geq 0.5$ を提示する。

2) $r_{q}=1.0$ の時の限界免震周期 $T_{f}$ とその時の最大水平変位 $\delta_{\max }$ の関係図 (図 9)，免震層の全せん断力係数 $\alpha_{1}$ (最大水平変位 $\delta_{\max }$ と免震周期 $T_{f}$ を含む）と安定した応答を維持するための低摩擦 型すべり支承の限界設置量の関係図（図10）を提示する。設計入 力地震動レベル $V_{E}$ と目標最大水平変位 $\delta_{\max }$ に応じて免震周期 $T_{f}$ の上限及び低摩擦型すべり支承の限界量 $R$ が定まる。

3 ）䅡層ゴムとダンパーに低摩擦型すべり支承を組合せた免震構造
のエネルギーの釣合に基づく応答予測式(21)，(25)では，せん断力比 $r_{q}$ を関数とする $n_{1}$ を導入する。この応答予測式は, 数值解析によ る応答値をほぼ包絡する安全側の評価をしている。またすべり支 承が無い状態 $R=0.0$ では，積層ゴムとダンパーからなる通常の 免震構造の応答予測式と一致している。この応答予測式を用いて, 設計の目安を付ける概略設計を行うことを考える。

4) 図 9 を用いて, 設計用地震動レベル $V_{E}$ と目標最大水平変位 $\delta_{\max }$ に応じた免震層の全せん断力係数 $\alpha_{1}$ を設定し, 免震周期 $T_{f}$ を求める(例えば図 9 中○印)。面圧を揃之るように，柱軸力をも とに積層ゴムを選定する。全て積層ゴムの時の免震周期 ${ }_{m} T_{f}$ を算 定する。図 9 より求めた免震層の全せん断力係数 $\alpha_{1}$ と目標最大水 平変位 $\delta_{\max }$ から図10を用いて, 負担せん断力比 $r_{q}=1.0$ を満たす 低摩擦型すべり支承の設置限界量を求める(例之ば図10中○印)。 さらに, 設計用地震動レベルを上回る地震動に对する余裕を確保 するために，低摩擦型すべり支承の設置限界量を下回る $R\left(r_{q}=\right.$ 1.0)を目標値として設定する(例えば図10中○印)。図10の $V_{E}$ 曲 線上の目標 $R\left(r_{q}=1.0\right)$ 值より, 目標全せん断力係数 $\alpha_{1}$ を定め, それに応じた免震周期 $T_{f}, \alpha_{s 1}\left(r_{q}=1.0\right)$ を定める。設定した低摩 擦型すべり支承の割合 $R$ になるように, 平面的なバランスを考之 ながら, 積層ゴムを低摩擦型すべり支承に置き換える。その際, 免震層の目標水平変位から決めた積層ゴムの最小径を下回るもの を優先的に置き換える。

5 ）設計用地震動レベル $V_{E}$ と免震周期 $T_{f}$ から無減衰時の応答せ ん断力係数 $\alpha_{0}$ を求める。エネルギーの釣合に基づく応答予測式 (21)，(25)を用いて，免震層の応答せん断力係数 $\alpha_{1}$ と最大水平変位 $\delta_{\max }$ が求まる。

6 ）ダンパーの選定にあたって, 水平剛性 $k_{s 1}$ は, 積層ゴムの水平剛 性 ${ }_{m} k_{f}$ に対して大きいほうが望ましい。 $k_{s 1}$ が小さいと十分な柔 要素の量が確保されていても，ダンパーの履歴塑性エネルギーは 小さくなり，等価繰返し数 $n_{1}$ を低下させる。

\section{参考文献}

1）日本建築学会：免震構造設計指針第 3 版, 2001.9

2）北村春幸：性能設計のための建築振動解析入門，彰国社，2002.9

3）北村春幸, 千葉陽一：稳層ゴムと弾性すべり支承を組合せた免震構造の工 ネルギーの釣合に基づく応答予测法，日本建築学会構造系論文集，第562 号, pp.37-44, 2002.12

4）秋山 宏：エネルギーの釣合に基づく建築物の耐震設計，技報堂出版， 1999.11

5）小山慶樹, 千葉陽一, 北村春幸：低摩擦型すべり支承と積層ゴム・ダンパー を組合せた免震構造のエネルギーの釣合に基つく応答評価（その 1，2）， 日本建築学会学術講演梗概集 (中部)，B-2, pp.449-452, 2003.9

6）秋山 宏：第 1 層エネルギ集中型柔剛混合構造の地震応答子測, 日本建築 学会構造系論文集，第 400 号，pp.77-87, 1989.6

7）高橋 誠, 秋山去：地震時における多層骨組の最大変形とエネルギー応 答，日本建築学会構造系論文集，第515号，pp.59-66, 1998.1

8）秋山宏,高橋 誠：地震時における柔剛混合せん断型多層骨組の残留変 形, 日本建築学会学術講演梗概集 (九州)， B-2, pp.397-398, 1998.9

（2003年 6 月 10 日原稿受理, 2003 年10月 27 日採用決定） 